\title{
BIODESULFURIZATION PROCESS EVALUATION WITH A Gordona rubropertinctus STRAIN
}

\author{
Julia Acero*, Claudia Berdugo and Leonardo Mogollón \\ Ecopetrol S.A. - Instituto Colombiano del Petróleo, A.A. 4185 Bucaramanga, Santander, Colombia \\ e-mail: jacero@ecopetrol.com.co
}

(Received 30 May 2003; Accepted 18 November 2003))

$\mathrm{D}$

irect combustion of fossil fuels produce sulfur oxides which are the main source of acid rain; therefore, most countries worldwide are regulating its release into the environment. As a consequence, several processes have been developed over the past years for desulfurization of crude oil and distillates. Due to its specificity, biodesulfurization is an interesting alternative for the transformation and upgrading of refined products, acting as a complement to traditional refining processes. This work presents an overview of Ecopetrol - Instituto Colombiano del Petróleo (ICP) efforts to develop a Biodesulfurization process, based on the activity of a native strain of Gordona rubropertinctus ICP1 72. Technical improvements on the isolation and characterization of desulfurizing microorganisms, the potential of developing new biocatalysts by means of directed evolution techniques, as well as the experience achieved during production of the biocatalyst in large-scale fermentation processes are hereby presented. The results of biodesulfurization reactions in conventional reactors and in a new membrane bioreactor prototype are also included. Finally, technological challenges faced by biodesulfurization processes are also discussed.

Keywords: biodesulfurization, non-aqueous biocatalysis, sulfur, SOx.

* To whom correspondence may be addressed 
os óxidos de azufre producto de la combustión directa de los combustibles fósiles son la principal fuente de lluvia ácida por lo cual la mayoría de países a nivel mundial regulan su liberación al medio ambiente. Como consecuencia, en los últimos años se han desarrollado diversos procesos para la remoción de azufre a partir del crudo y sus derivados. La biodesulfurización, por su alta especificidad se presenta como una alternativa prometedora en la transformación y valorización de productos refinados, como tecnología complementaria a las prácticas de refinación tradicionales. Este trabajo resume los esfuerzos realizados en Ecopetrol - Instituto Colombiano del Petróleo (ICP) en el desarrollo de un proceso de Biodesulfurización con una cepa nativa de Gordona rubropertinctus ICP172. Se presentan los avances técnicos obtenidos en el aislamiento y caracterización de los microorganismos desulfurizadores, el potencial de desarrollo de nuevos biocatalizadores por técnicas de evolución dirigida así como la experiencia obtenida en la producción del biocatalizador en fermentaciones a gran escala. Así mismo se presentan los resultados obtenidos en reacciones de desulfurización en reactores convencionales y en un nuevo prototipo de reactor de membrana. Finalmente se discuten los retos tecnológicos que un proceso de Biodesulfurización tendrá que enfrentar para lograr su aplicación a escala industrial.

Palabras claves: biodesulfurización, biocatálisis anhídra, azufre, SOx. 


\section{INTRODUCTION}

As a whole, industrial development has been accompained by the environments' deterioration, of which its primary manifestations are global warming, acid rain and destruction of the ozone layer. In their efforts to protect the environment and to guarantee the welfare of future generations, governments have implemented legislations intended to regulate atmospheric emissions, liquid disposals, and solid waste products generated by industrial activities. The Oil industry has not been the exception being subject to laws intended to diminish atmospheric emissions generated by hydrocarbons combustion, mainly, carbon dioxide (involved in global warming or greenhouse effect), and nitrogen (NOx) and sulfur (SOx) oxides implied in the acid rain phenomenon. As a result, the United States Environmental Protection Agency- EPA and other regulatory agencies worldwide have limited the amount of sulfur dioxide released into the air and, consequently, the content of sulfur in fuels, especially diesel oil and gasoline. In Colombia, the Ministry of the Environment, through Resolution 0068 issued in January 18, 2001, set forth the new quality standards for fuels in terms of maximum organic sulfur concentrations allowed (Table 1).

Conventional processes of sulfur removal such as hydro-treatment exhibit important technical and economical problems to achieve the sulfur levels required by international treaties. This technology makes intensive use of energy since transformations occur at high temperature and pressure conditions, and operating costs grow geometrically when trying to reduce very low sulfur concentrations (less than 500 ppm). Nevertheless, hydrodesulfurization (HDS) has made substantial progress for the last years with the development of new catalysts and with the development of a process that can reach drastic standards (10 ppm of sulfur) in a near future. On the other hand, nonconventional technologies such as chemical oxidation (Levy et al., 2001), selective adsorption of sulfurated compounds (www.szorb.com/szorb_processover.htm), or biodesulfurization (Monticello, 2000; Ohshiro and Izumi, 1999), are alternatives under development for the production of diesel oil and gasoline with low sulfur contents (Fredrick, 2002).

Microbial desulfurization or biodesulfurization is described as the process by which the use of a catalyst of biological nature enables the removal of sulfur content in oil fractions at moderate pressure and temperature conditions. Given its specificity, it is presented as a promising alternative for the removal of organic-sulfured molecules resistant to conventional technologies, such as dibenzothiophenes and their substituted forms (Monticello, 1998). Development of a biodesulfurization process includes the isolation and production of the biocatalyst (microorganism or enzyme), the desulfurization reaction (non-aqueous biocatalysis), and finally, the separation of products and quality controls. Most recent papers in this area describe significant efforts intended to isolate new desulfurizing microorganisms as well as the genetic improvement of such microorganisms. In the same way, significant advances are observed worldwide in terms of biocatalysis in the organic

Table 1. New quality standards for fuels in terms of maximun organic sulfur concentrations allowed in Colombia. Resolution 0068 (January 2001)

\begin{tabular}{|c|c|c|}
\hline Fuel & Due date & $\begin{array}{c}\text { Maximum sulfur } \\
\text { (\% MASS) }\end{array}$ \\
\hline \multirow[t]{2}{*}{ Gasoline } & January 1, 2001 & 0,1 \\
\hline & January 1, 2005 & 0,03 \\
\hline \multirow[t]{2}{*}{ Diesel } & January 1, 2001 & 0,45 \\
\hline & January 1, 2005 & 0,05 \\
\hline \multirow[t]{2}{*}{ Fuel oil } & January 1, 2001 & 1,7 \\
\hline & January 1, 2005 & 1,5 \\
\hline
\end{tabular}

Colombia. Ministry of the Environment.

Resolution 0068 issued in January 18, 2001. 
or anhydrous phase and in the field of bioengineering as a whole, where concepts of metabolic engineering (biocatalyst design), construction of new bioreactors and development of sophisticated separation systems are combined. (Vazquez-Duhalt et al., 2002; Boron et al., 1999).

Different desulfurizing microorganisms have been isolated and characterized worldwide, including Rhodococcus erythropolis IGTS 8 (Kilbane and Bielaga, 1990), Rhodococcus erythropolis D-1 (Izumi et al., 1994), Rhodococcus erythropolis I-19 (Folsom et al., 1999), and Rhodococcus sp strain WU-K2R (Kirimura et al., 2002). These microorganisms transform Dibenzothiophene (DBT) into 2-hydroxybiphenyl (2-HBP), which remains in the organic phase while the sulfur is eliminated in the form of inorganic sulfate in the aqueous phase of the system. Out of these strains, Rhodococcus erythropolis IGTS 8, as isolated and patented by Enchira Biotechnology Corporation (formerly Energy Biosystem Corporation), has been studied in detail; its metabolic route has been established through the identification of the enzymes and genes responsible for its desulfurizing activity (Gray et al., 1996; Piddington et al., 1995; Denome et al., 1994)(Figure 1). More recently highlight should be made on the isolation and characterization of thermophile strains such as Paenibacillus sp., capable of desulfurizing benzo- and dibenzothiophenes present in diesel oil (Konishi, J., 2000; Yoshitaka et al., 2000), as well as the development of several evolution techniques aimed at modifying and obtaining enzymes with new and/or improved characteristics (Arnold et al., 2001).

In the fields of biocatalysis in organic phase and bioengineering, important progress has been made with the design of new bioreactors. Proposals include the use of electro spray type reactors (Kaufman et al., 1997) or membrane reactors, which favor the contact between the organic and aqueous phases (Berdugo et al., 2002, Setti et al., 1999 ) and biphasic reactors with and without the reuse of biomass through immobilization of microorganisms.

The purpose of this paper is to present the most relevant achievements in the development of a Biodesulfurization technology at Ecopetrol - Instituto Colombiano del Petróleo through the evaluation of strain Gordona rubropertinctus ICP172. Technical advances in the isolation, characterization and genetic improvement of biocatalysts, as well as the experience acquired in organic phase biocatalysis are effectively displayed. Finally, the technological challenges that this technology has to overcome in the upcoming decades in order to be successfully applied at industrial levels, are brought up.

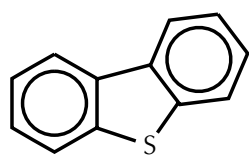

Dibenzothiophene
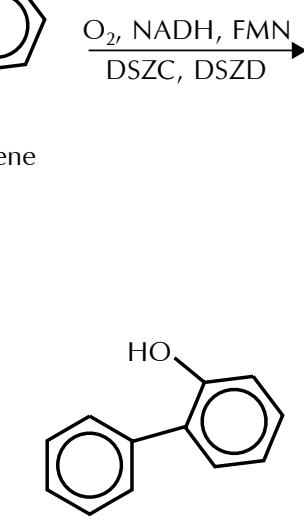

2-Hydroxybiphenyl

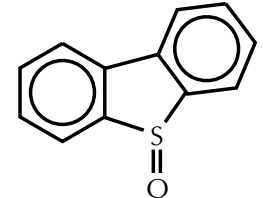

Dibenzothiophene sulfoxide

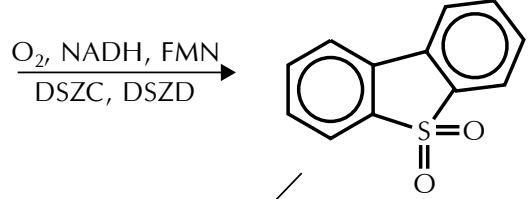

Dibenzothiophene sulfoxide
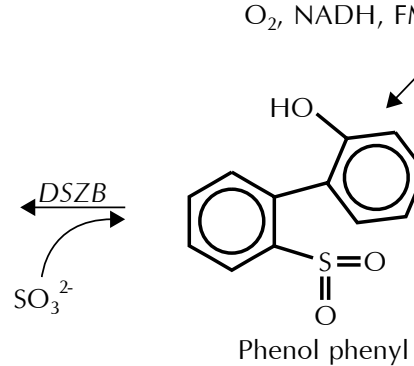

sulfinate

Figure 1. Desulfurization of Dibenzothiophene by strain Rhodococcus erythropolis IGTS8. DszC, DBT-monooxygenase; DszA, DBTO monooxygenase; DszB, HPBS desulfinase; DszD, FMN flavin mononucleotide reductase (Gray et al., 1996) 


\section{METHODOLOGY}

\section{Biocatalysts and culture-related conditions}

Microorganisms and plasmids used in this study are shown in Table 2. Desulfurizing strain where grown at $305 \mathrm{~K}$ in basal salt medium ICP4, containing (g/1): Glucose 12,4; $\mathrm{Na}_{2} \mathrm{HPO}_{4} 3,74 ; \mathrm{KH}_{2} \mathrm{PO}_{4} 1,68 ; \mathrm{NH}_{4} \mathrm{Cl} 2,84$; $\mathrm{MgCl}_{2} \cdot 6 \mathrm{H}_{2} \mathrm{O} 0,146 ; \mathrm{FeCl}_{3} .6 \mathrm{H}_{2} \mathrm{O} 0,02 ; \mathrm{CaCl}_{2} \cdot 2 \mathrm{H}_{2} \mathrm{O}$ 0,112; dimethylsulfoxide (DMSO) 0,02 . The E. coli transforming strains were grown in LB medium supplemented with ampicillin $(100 \mu \mathrm{g} / \mathrm{ml})$, at $310 \mathrm{~K}$. Fed batch culture conditions were published in Berdugo et al. (2001). The dszC gene used in the directed evolution trials was amplified and cloned from strain ICP172. dszC mutants were obtained via Error-prone PCR (EPPCR) technique as described in Acero (2002).

\section{Fed batch culture}

To increase the amount of biocatalyst for the desulfurization reactions, several fed batch cultures with constant and exponential flow, were grown in a New
Brunswick Bioflo 3000 reactor. The fermentor has temperature, dissolved oxygen and air flow control. Cultures were grown in ICP4 medium, which contains glucose as carbon source and DMSO as sulfur source. Culture conditions and operational conditions are presented in detail in Berdugo et al. (2001).

\section{Biodesulfurization reactions}

Once the biomass is obtained through the aforementioned procedures, biomass activity is verified via the production of 2-HBP metabolite. Desulfurization reactions are carried out through a "resting cells" procedure, using $20 \mathrm{~g} / \mathrm{l}$ of biomass (respect to the total volume) and $25 \%$ organic phase. Reactions were carried out with a model compound (DBT in hexadecane) and Diesel oil emulsions in 0,2 liters, 1 liter, and 5 liters reactors, respectively. Detailed procedure is described in Berdugo et al. (2001). The membrane bioreactor is composed of a carcass and a membrane, arranged as two concentric tubes. The carcass was made in $1 / 2$ inch diameter tubing with two ports, used for fluid input and output. The membrane ends are isolated from the carcass in such a

Table 2. Microorganisms and plasmids used in this study

\begin{tabular}{|c|c|}
\hline $\begin{array}{l}\text { Microorganisms and } \\
\text { Plasmids }\end{array}$ & Description \\
\hline ICP52 & $\begin{array}{l}\text { Rhodococcus erythropolis IGTS8 } \\
\text { Control desulfurizing strain }\end{array}$ \\
\hline ICP172 & $\begin{array}{l}\text { Gordona rubropertinctus } \\
\text { Native desulfurizing strain }\end{array}$ \\
\hline ICP7 & $\begin{array}{l}\text { E.coli NC3 with plasmid pSAD225-32 (dszABC } \\
\text { operon of strain IGTS8) }\end{array}$ \\
\hline ICP326 & $\begin{array}{l}\text { E.coli JM109 } \\
\text { Genomic library amplification }\end{array}$ \\
\hline ICP327 & $\begin{array}{l}\text { E. coli JM109 DE3 } \\
\text { Recombinant proteins expression }\end{array}$ \\
\hline ICP342 & E. coli DE3/pJA-C172 \\
\hline ICP343 - ICP 363 & $\begin{array}{l}\text { E. coli DE3 } \\
\text { E. coli transformants with } d s z C \text { mutant genes }\end{array}$ \\
\hline pGEMEX ${ }^{\circledR}-2$ & Expression Vector (Promega) \\
\hline pJA-C 172 & $\begin{array}{l}\text { Recombinant plasmid with dszC gene from } \\
\text { ICP } 172 \text { strain }\end{array}$ \\
\hline $\begin{array}{l}\text { pJA-C } 343 \text { to } \\
\text { pJA-C } 363\end{array}$ & $\begin{array}{l}\text { Series of Recombinant plasmids containing } d s z C \\
\text { mutated genes }\end{array}$ \\
\hline
\end{tabular}


way that the fluid from the carcass only passes to the membrane if it moistens the teflon membrane. Additional data is recorded in Berdugo et al. (2002).

\section{Analytical methods}

Total sulfur was determined by gas chromatography with photometric flame detector. Dimetilsulfoxide (DMSO) was determined by HPLC (High performance liquid chromatography). Dibenzothiophene (DBT), Benzothiophene (BHT) and 2-hidroxibiphenyl (2-HBP) were monitored by gas chromatography with ionizing flame detector (GC/FiD). DBT, BHT and 2-HBP were obtained from Aldrich Chemicals. All other reagents were analytical grade.

Secondary metabolites analysis was carried out through solid phase microextraction technique. Analyses were carried out by gas chromatography with flame photometric detector (HRGC/FDP) and mass selective detector (HRGC/MSD). Standardization of the technique comprised the evaluation of parameters such as temperature, $\mathrm{pH}$, salt concentration, and the stationary phase type (Polydimethylsiloxane/divinylbencene - 65 $\mu \mathrm{m}$ and polyacrylate $-85 \mu \mathrm{m})$. The metabolite extraction and quantification procedure is reported in Puerta and Staschenko (2000). The Chromatograph used for GC-MSD was HP-5890 Series II (Hewlett-Packard, Palo Alto, Ca., USA), connected to a selective mass detector (HP-5972); and for HRGC/FPD, a HP-5890 model (Hewlett-Packard, Palo Alto, Ca., USA).

\section{RESULTS AND DISCUSSION}

In Colombia, Ecopetrol - Instituto Colombiano del Petroleo had the opportunity to evaluate the potential of a Biodesulfurization process as an innovative and complementary technology for the reduction of the organic sulfur levels present in diesel oil. The development of the process included a first stage for the isolation and characterization of a suitable biocatalyst; that is, the selection of desulfurizing microorganisms and the development of new and improved biocatalysts by genetic improvement of some enzymes. A second stage included the production of high cell density cultures of the biocatalyst and the assessment of its efficiency in desulfurization reactions. Technical advances of each stage are shown below.

\section{Isolation and development of suitable biocatalysts}

Initially, 60 native strains were isolated from natural sources and oil residues by means of enrichment culture and direct isolation techniques (Madero et al., 1998). Strains were subjected to specific selective tests in synthetic solutions (Didenzothiophene in ethanol, Dibenzothiophene in hexadecane) and real matrixes (diesel oil and kerosene). Of these, strain ICP172 showed the capacity to assimilate and use sulfur contained in Dibenzotiophene (DBT) and in diesel oil, as the only growing sulfur source. The strain was characterized at a biochemical and molecular level to identify the metabolic route and enzymes used by the microorganism for the transformation of DBT. Biochemical identification of the microorganism using Microstation $^{\mathrm{TM}}$ BIOLOG system version 3,5, revealed a Gordona rubropertinctus strain with a similarity percentage of 0,942 . Molecular characterization of strain ICP172 included the identification and further cloning of the desulfurizing genes $d s z A, d s z B$ and dszC using strain IGTS8 genes as a probe.

Since biocatalytic activity of the strain may be genetically improved, a directed evolution experiment was designed for the improvement of the Dibenzothiophene monooxygenase enzyme (DszC), which is responsible for the initial oxidation of the sulfur compounds. dszC gene mutants were obtained by Error-Prone PCR (EP-PCR), a directed evolution technique previously standardized and evaluated in our Laboratory for the development of hydrophobic and thermo-tolerant Chloroperoxidase enzymes (Acero and Mogollón, 2002). dszC gene from strain Gordona rubropertinctus ICP172 was cloned and amplified in EP-PCR reactions. Mutated genes $(1,3 \mathrm{~kb})$ were further purified and cloned in vector pGEMEX-2 for transformation in competent E. coli cells. Strains ICP343 through ICP363 were selected for the evaluation and expression of DszC monooxygenases. Strain ICP 345 reacted to the induction with IPTG with the production of a fusion protein of approximately $65 \mathrm{kDa}$ (Figure 2). Fusion protein was solubilized, partially purified and evaluated for its capacity to oxidize indol into indigo as a preliminary test for monooxygenase activity. Positive clones may be expressed in a Gordona rubropertinctus dszC (-)strain, and their activities compared with native DszC enzyme. An efficient biodesulfurization process could include a pre-oxidation stage with improved 


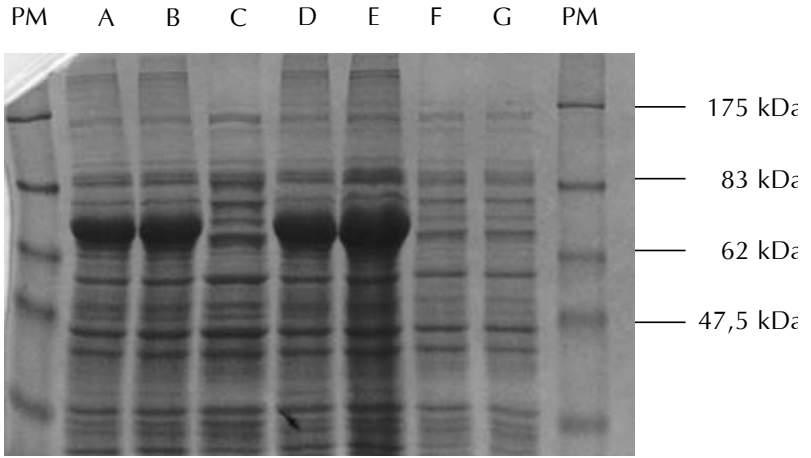

Figure 2. SDS-PAGE analysis of recombinant E. coli strains expressing dsz $C$ mutant genes induced with IPTG. A: Strain ICP345 (3 hours of induction); B: ICP345 (4 hours); C: Strain JM109;

D: ICP345 (5 hours); E: ICP345 (overnight induction); F: Strain JM109 DE3. PM: Pre-stained Molecular Weight Marker (New Englands Biolabs)
DszC enzymes complemented with a liquid/liquid extraction step or the removal of oxidized compounds during Catalytic Cracking.

\section{Metabolic route identification of strain ICP172}

To confirm the metabolic route followed by Gordona rubropertinctus ICP172 strain in the biodesulfurization process, an identification of intermediate metabolites was performed through solid phase microextraction technique (Janusz, 1997). Assessments carried out through gas chromatography with photometric flame detector and mass selective detector, enabled the identification and quantification of sulfured metabolites: Dibenzothiophene (DBT), N-butyl-bencenesulfonamide, dibenzo[c,e][1,2]oxatiine 6-oxide (Sultine), DBT-sulfone, and three more unidentified intermediate compounds (Puerta and Staschenko, 2000). Figure 3

(A)

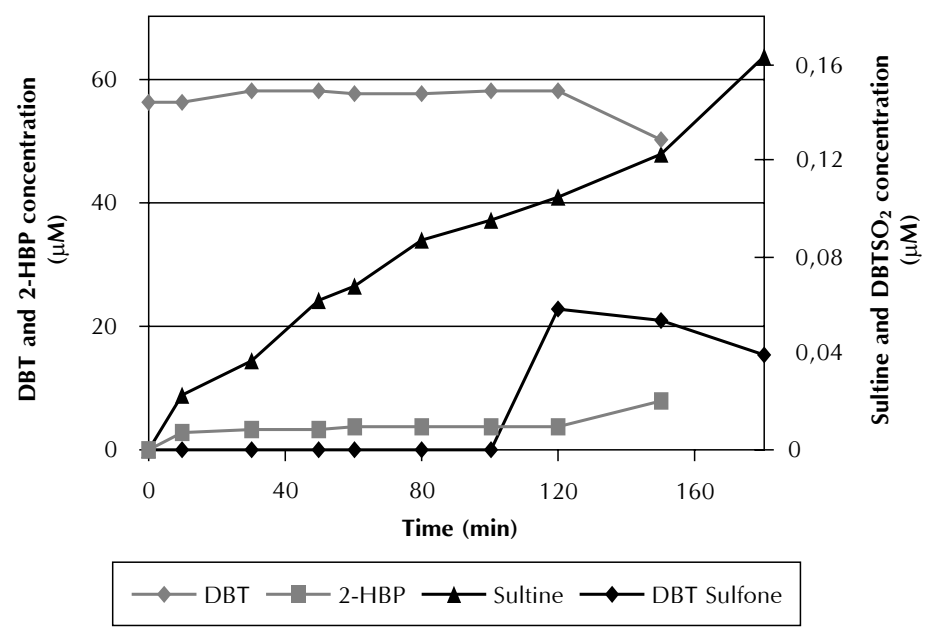

(B)
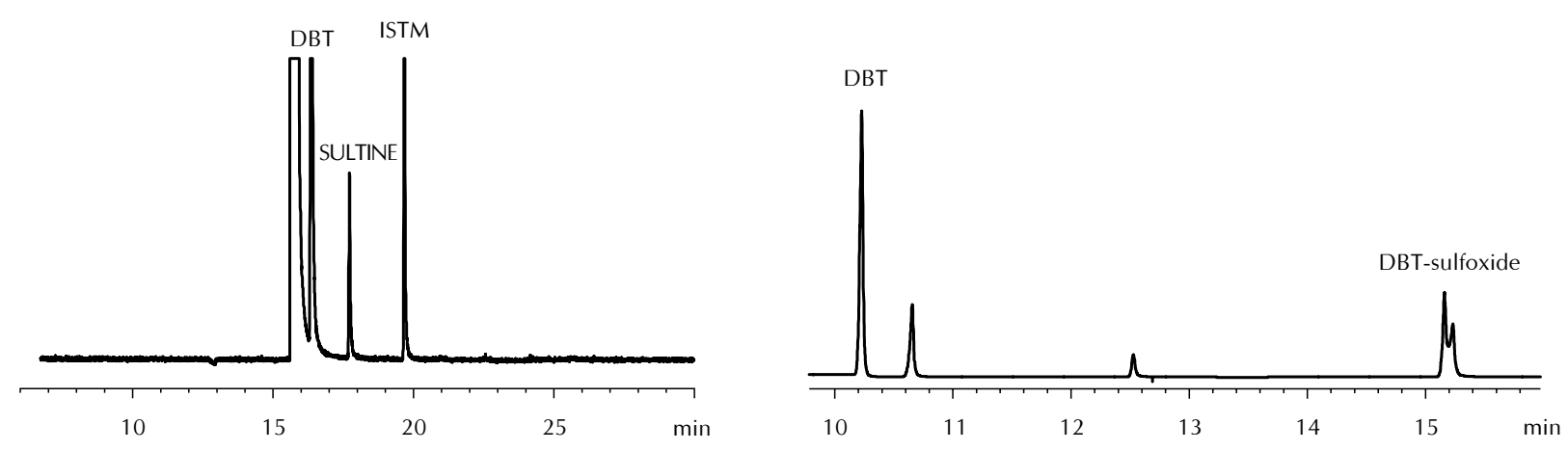

Figure 3. Identification of the metabolic route of strain ICP172. (A) Biotransformation kinetics of DBT. (B) Chromatograms of biodesulfurization reactions, identification of intermediate metabolites obtained by solid-phase microextraction technique and gas chromatography 
shows the transformation kinetics of Dibenzothiophene by strain ICP172, and the chromatograms with the identification of the intermediate metabolites. Identification of these sulfur compounds allowed confirming that strain ICP172 follows the $4 \mathrm{~S}$ or non-destructive desulfurizing route, as suggested before.

\section{Production of the biocatalyst}

For a large-scale production of the biocatalyst, two fed batch-culture strategies were evaluated: fed batch culture at constant rate and fed batch culture at exponential rate. Trials were carried out with Rhodococcus erythropolis IGTS8 strain as a standard strain, and with the native Gordona rubropertinctus ICP172 strain. For the development of fed batch cultures, flux profiles by automated feeding systems were established (Berdugo et al., 2001). Fed batch cultures at constant flux for strain IGTS8 drove an increase in cellular concentration, reaching a density of $4,5 \mathrm{~g} / \mathrm{l}$ of biomass. This concentration is 1,5 times higher than the achieved in batch cultures and features the same order of magnitude reached by Wang and Krawieck (1996), who used a culture strategy similar to the one reported herein. However, a limitation by substrate or inhibition by byproducts was observed, which prevented the development of higher cellular concentrations.

In the fed batch culture, exponential flux, the dilution rate remains constant; therefore, a dilution rate equivalent to the maximum culture growth speed was fixed. (Berdugo et al., 2001). Figure 4A shows the kinetic behavior of the fed batch culture-exponential flux of strain IGTS8. Under these conditions, it is pos- sible to increase the cellular concentration up to 7,5 $\mathrm{g} / 1$, which is three times that of batch culture, and 1,7 times that reported by Wang and Krawiec (1996). On the other hand, the kinetic behavior of the fed batch culture- exponential flow of native strain ICP172 is shown in Figure 4B. Initially in-batch stage, the microorganisms growth rate was $0,0015 \mathrm{~h}-1$; therefore, the dilution rate corresponded to this same value. Afterwards, this value was recalculated, considering the low cellular growth during these first hours. The system was then operated with a dilution rate of $\mathrm{D}=0,01 \mathrm{~h}-1$, until reaching a total volume of 12 litres. Under these conditions, it was possible to increase the cellular concentration up to $12,5 \mathrm{~g} / 1$. This value is close to the one obtained by Folsom et al. (1999) with strain IGTS8. This results are satisfactory considering that only a few groups have developed a high density culture strategy with desulfurizing strains. Honda et al. (1998) developed a high density culture strategy with strain IGTS-8 obtaining cellular concentrations of 30 $\mathrm{g} / \mathrm{l}$ in a fed-batch culture.

In all cases of biocatalyst production, the biomass obtained was catalytically active in the biodesulfurization trials performed with DBT/HXD matrix and in-diesel. A positive criterion was the detection of the final metabolite, 2-hidroxybiphenyl (2-HBP) by chromatography (data not shown).

\section{Development of a membrane reactor prototype}

Reactors traditionally used in biosulfurization processes (stirred tanks) present several limiting aspects for its application at an industrial level, these reactors
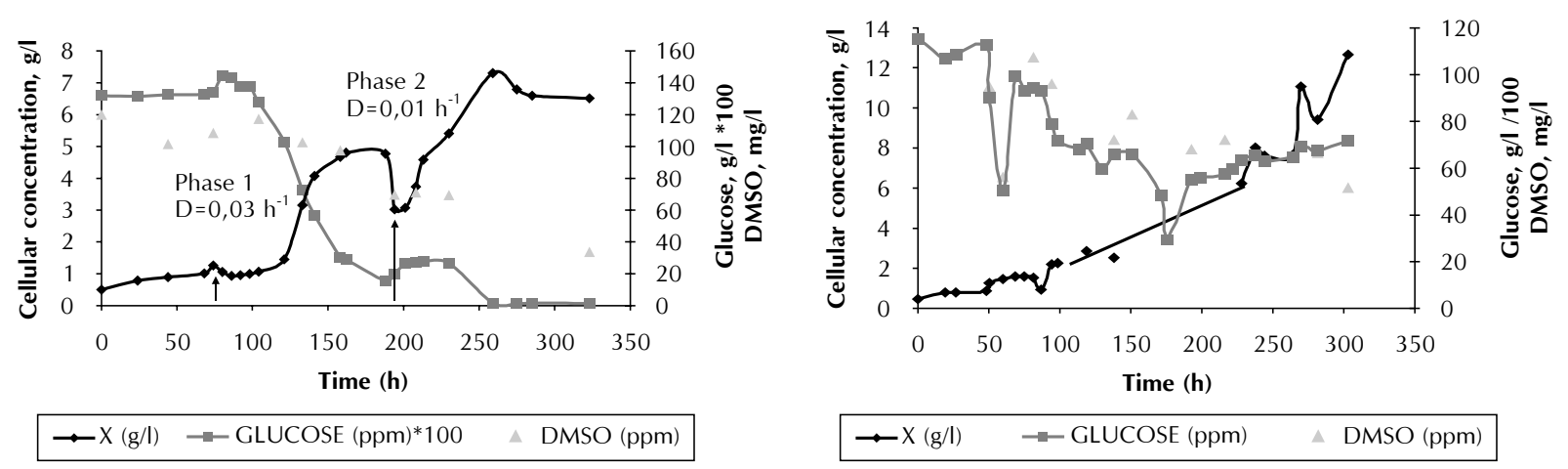

Figure 4. Fed-batch culture strategy with exponential flux of strains IGTS8 (A) and ICP

172 (B). Arrows indicate feeding profiles 
(a)

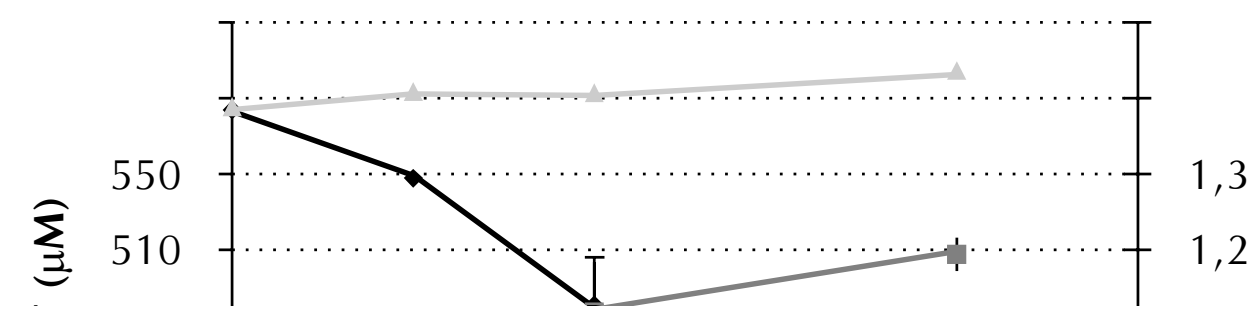

Figure 5. Transformation Kinetics of Dibenzothiophene (A) and Benzothiophene (B) in biodesulfurization reactions by strain Gordona rubropertinctus ICP172

feature organic phase/watery phase volumetric ratios that do not exceed the $50 \%$ mark, to avoid microbial inhibition and formation of stable water-oil emulsions. Thus giving importance to the design of new bioreactors. Among the non-conventional reactors that have been used at industry levels, membrane reactors have attracted considerable interest due to its possibility of integrating the biocatalytic and the separation processes in-one. Membrane bioreactors combine selective mass transportation featuring chemical reactions with the selective removal of inhibitory products from the process, thus increasing reaction conversion (Giorno and Drioli, 2000). Through this system it is possible to immobilize cells or enzymes, and to simultaneously reach bioconversion, product separation and enrichment in the same operating unit (Belfort, 1989 quoted in Cass et al., 2000).

Due to the aforementioned, a membrane bioreactor prototype was designed, built and further assessed during biodesulfurization processes. The system was also used as a separation mechanism for the emulsion developed during the biocatalytic reaction. The reactor operates as a tube and carcass-type interchanger, where it is possible to separate the organic phase, using hydrophobic membranes on the tubing coating through which the emulsion is loaded into the carcass; the organic phase is recovered through the lumen. Two sets of experiments where carried out. In the first one, the emulsion separation was evaluated at different cellular concentrations, keeping the organic/aqueous phase relation of 25/75. In the second set of trial, the separation of phases at different organic/aqueous ratios (60/40, $50 / 50,40 / 60$ y $25 / 75)$ was evaluated, with a cellular concentration of 3 and $7 \mathrm{~g} / 1$ (Berdugo et al., 2002). Trials carried out with a cellular concentration of $3 \mathrm{~g} / \mathrm{l}$ and at different organic phase ratios, showed that a greater organic/aqueous ratio, allows a more effective phase separation. Trials where reproduced at $60 / 40$ and 40/60 ratios. On the other hand, for a cellular concentration of $7 \mathrm{~g} / \mathrm{l}$, phase separation was similar for $60 / 40$ and $50 / 50$ phase ratios. A smaller separation capacity was observed for a organic/ aqueous phase ratio of 40/60.

\section{Biodesulfurization reactions}

Biodesulfurization reactions were performed by using dibenzothiophene (DBT) in hexadecane (HXD) and Diesel as a matrix in stirred tank reactors in scales of $200 \mathrm{ml}, 1$ liter and up to 5 liters of reaction volume. Figure 5 presents the transformation kinetics of dibenzothiophene (DBT) and benzothiophene (BT) by strain ICP172 in desulfurization reactions through a "resting cells" technique. Biodesulfurization reactions were developed with the biomass produced by fed batch cultures (constant and exponential flux). Biomass activity was determined through the detection of 2-HBP, the final metabolite of the $4 \mathrm{~S}$ desulfurization route. In these reactions, the sulfur removal level differed according to the operation conditions; however, in all cases the removal levels were approximately $10 \%$ of total sulfur. Although these removals are still to low to comply with the standards set forth in international agreements, these efficiencies can be improved through different strategies, including the improvement of the biocatalyst, the design o new bioreactors and the design of a sequential biodesulfurization reaction process with serial reactors. 


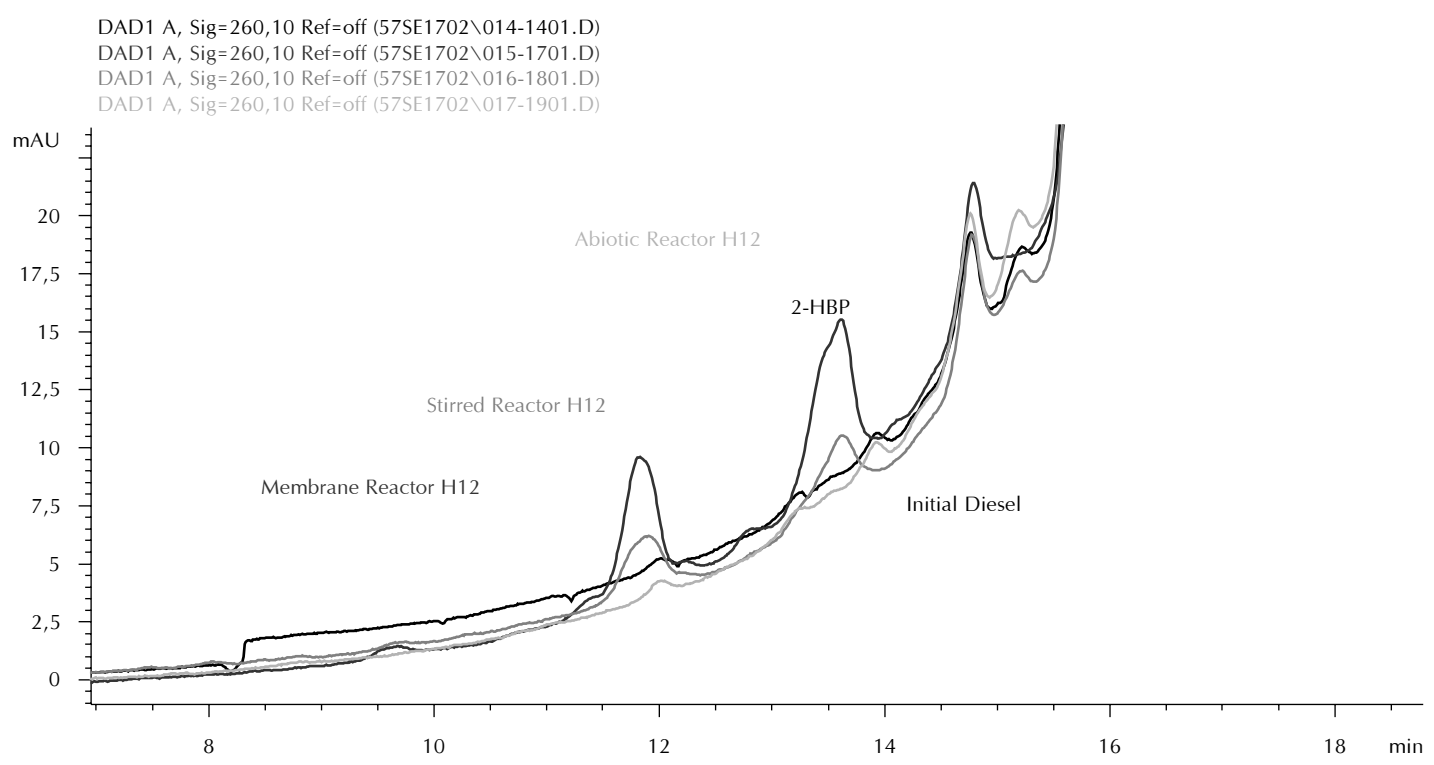

Figure 6. Biodesulfurization reactions within the membrane reactor: 2-HBP detection. Comparative study between membrane bioreactor, stirred-tank bioreactor (STR) and a non-biotic system. Diesel as the initial matrix

Biodesulfurization reactions performed within the membrane reactor prototype allowed the detection of final metabolite 2-HBP, as observed in Figure 6. These preliminary evaluations show a qualitative analysis between a non-biotic system, a normal stirred-tank bioreactor (STR) and a membrane bioreactor. The latter showed a great potential for the improvement of biodesulfurization reactions and the development of new catalytic/separation systems.

\section{FINAL CONSIDERATIONS}

The oil industry currently faces one of its greatest challenges: to optimize hydrocarbon production and transformation processes, in order to obtain more efficient and cleaner products, that meet international quality regulations and $\mathrm{CO}_{2}, \mathrm{SOx}$, and $\mathrm{NOx}$ emission controls. In this regard, we have analyzed how development of biocatalytic processes featuring high efficiency and specificity levels can become an alternative to the traditional refining processes. Around the world, several microorganisms have been identified that possess the potential to drive biotransformation of crude oil and its derivatives. Many of these microorganisms have been genetically modified and many are still to be discovered, featuring new and better characteristics, which may turn processes such as biodesulfurization into a reality. At the Instituto Colombiano del Petróleo, significant advances have been achieved within the Latin American context, achieving the identification and improvement of some biocatalysts that may be useful in the development of such processes. Also, advances have been made in the organic phase biocatalysis and crude oil bioprocessing areas. Emphasis on these areas will help to overcome current technological barriers preventing the biodesulfurization process from being successfully applied at industrial level. The future of biorefining will likely take into consideration mixed, chemical and/or biological processes, that may satisfy the very particular needs of the oil industry, as recently proposed by Vazquez-Duhalt et al. (2002) in their prospective analysis on the impact biochemical catalysis might have on the oil industry. Vazquez-Duhalt (2002) present advances and impact of biorefining processes (desulfurization, denitrogenation, heavy metal removal, asphaltane processing, etc.) on an international context. They conclude, as we do, that alternate or complementary biotechnological processes for traditional refining can significantly increase the energetic efficiency and reduce the environmental impact of current refining operations through the development of the areas considered in this study. 


\section{ACKNOWLEDGEMENTS}

The authors wish to express their gratitude to Ecopetrol - ICP for the economical support in the development of this study. Special gratitude to the research group in Biorefining for their support and technical contribution in the development of Hydrocarbons Biodesulfurization project. Likewise, acknowledgement should be made to the technical support provided by the Chromatography Laboratory of Universidad Industrial de Santander, specially to Dr. Helena Stashenko and Dr. Miguel Angel Puerta in the elucidation of the microorganisms metabolic route.

\section{BIBLIOGRAPHY}

Acero, J. R. and Mogollón, L., 2002. "Desarrollo de biocatalizadores hidrofóbicos y termotolerantes mediante técnicas de evolución dirigida". Revista Colombiana de Biotecnología, Vol IV (1): 14-20.

Acero, J., 2002. "Development of DBT-monooxygenase mutants by directed evolution for organic sulfur removal”. Proceedings 9th Int Petroleum Environmental Conference, October, Albuquerque, NM, USA.

Arnold, F. H., Wintrode, P. C., Miyazaki, K. and Gershenson, A., 2001. "How enzymes adapt: lessons from directed evoluction". Trends in Bioch. Sci., 26: 100-106.

Berdugo, C., Caballero, C. and Godoy, R. D., 2002. "Aqueous-organic phases separation by membrane reactors in biodesulfurization reactions". CT\&F-Ciencia, Tecnología and Futuro, 2 (3): 97-112.

Berdugo, C., Mena, J., Acero, J. and Mogollón, L., 2001. "Increasing the production of desulfurizing biocatalysts by means of fed-batch culture". CT\&F-Ciencia, Tecnología and Futuro, 2 (2): 7-15.

Boron, D., Deever, W., Atlas, R., McFarland, B., Meyer, J. and Johnson, A., 1999. "Biodesulfurization of gasoline: an assessment of technical and economic feasibility and outline of $R$ and D roadmap toward commercialization". NPRA Annual Meeting, March, San Antonio,Texas, USA.

Cass, B. J., Schade, F., Robinson, C. W., Thompson, J. E. and Legge, R. L., 2000. "Production of tomatoe flavor volatiles from a crude enzyme preparation using a hol- low-fiber reactor". Biotechnology and Bioengineering, 67 (3): 372-377.

Denome, S., Oldfield, C., Nash, L. and Young, K. C., 1994. "Characterization of the desulfurization genes from Rhodococcus sp. strain IGTS8”. J. Bacteriol., 176: 6707-6716.

Folsom, B. R., Schieche, D. R., Dgrazia, P. M., Werner, J. and Palmer, S. K., 1999. "Microbial desulfurization of alkylated dibenzothiophenes from a hydrodesulfurized middle distillate by rhodococcus erythropolis I-19". Applied and Environmental Microbiology, 65 (11): 4967-4972.

Fredrick, C., 2002. "Sulfur reduction: what are the options?". Hydrocarbon Processing, February, 45-50.

Giorno, L. and Drioli, E., 2000. "Biocatalytic membrane reactors: applications and perspectives". Tibtech., 18: 339-349.

Gray, K., Pogrebinsky, O., Mrachko, G., Xi, L., Monticello, D. and Squires, C., 1996. "Molecular mechanisms of biocatalytic desulfurization of fossil fuels". Nature Biotechnol., 14: 1705-1709.

Honda, H., Sugiyama, H., Saito, I. and Kobayashi, T., 1998. "High cell density culture of rhodococcus rhodochrous by $\mathrm{pH}-\mathrm{Stat}$ feeding and dibenzothiophene degradation". Journal of Fermentation and Bioengineering, 85 (3): 334-338.

Izumi, Y., Ohshiro, T., Ogino, H., Hine, Y. and Shimao, M., 1994. "Selective desulfurization of dibenzothiophene by Rhodococcus erythropolis D-1". Appl. Environ. Microbiol., 60: 223-226.

Janusz, P., 1997. "Solid phase microextraction: theory and practice”. Wiley - VCH, Inc., New York, USA.

Kaufman, E., Harkins, J., Rodríguez, M., Tsouris, C., Severaj and Murphy, S., 1997. "Develoment of an electro-spray biorreactor for crude oil processing”. Fuel processing Technology, 52: 127- 144.

Kilbane, J. J. and Bielaga, B. A., 1990. "Towards sulfur-free fuels". Chem.Tech. Dec., 747-751.

Kirimura, K., Furuya, T., Sato, R., Ishii, Y. Kino, K. and Usami, S., 2002. "Biodesulfurization of naphthothiophene and benzothiophene through selective cleavage of carbon-sulfur bonds by rhodococcus sp. strain WU-K2R". Appl. Environ. Microbiol., 68 (8): 3867-3872. 
Konishi, J., Onaka, T., Ishii, Y. and Suzuki, M., 2000. “Demonstration of the carbon-sulfur bond targeted desulfurization of benzothiophene by thermophilic paenibacillus sp. Strain A11-2 capable of desulfurizing dibenzothiophene". FEMS Microbiology, 187: 151-154.

Levy, R., Rappas, A., Decanio, S. and Nero,V., 2001. "UniPure's ASR-2 desulfurization process provides costeffective solution for ultra low sulfur refined products". NPRA Annual Meeting, March.

Madero, A., Mogollón, L., Mora, A. and Osorio, L., 1998. "Selección de microorganismos mesófilos biodesulfurizadores". CT\&F-Ciencia, Tecnología and Futuro, 1 (4): 93-100.

Monticello, D. J., 2000. "Biodesulfurization and the upgrading of petroleum distillates". Current Opinion in Biotechnology, 11: 540-546.

Monticello, D. J., 1998. "Riding the fossil fuel biodesulfirization wave". Chemtech., 28 (7): 38-45.

Ohshiro, T. and Izumi, Y., 1999. "Microbial desulfurization of organic sulfur compounds in petroleum". Biosc. Biotechnol. Biochem., 63 (1): 1-9.

Piddington, C., Kovacevich, B. and Rambosek, J., 1995. "Sequence and molecular characterization of a DNA region encoding the dibenzothiophene desulfurization operon of rhodococcus sp, strain IGTS8". Appl. Environ. Microbiol., 61: 468-475.

Puerta, M. A. and Staschenko, H., 2000. “Informe- análisis de los metabolitos producidos durante el proceso de biodesulfurización de la cepa ICP172”. Laboratorio de Cromatografía, Universidad Industrial de Santander. Bucaramanaga, Colombia.

Setti, L., Farinelli, P. and Di Martino, S., 1999. "Development in destructive and nondestructive pathways for selective desulfurizations in oil-biorefinig processes". Appl. Microbiol. Biotechnol., 52: 111-117.

Vazquez-Duhalt, R., Torres, E., Valderrama, B. and Le Borgne, S., 2002. "Will biochemical catalysis impact the petroleum refining industry?". Energy and Fuels, 16: 1239-1250.

Wang, P. and Krawiec, S., 1996. "Kinetic analyses of desulfurization of dibenzothiophene by rhodococcus erythropolis in batch and fed-batch cultures". Applied and Environmental Microbiology, 62 (5): 1670-1675.
Wang, P., Humphrey, A. E. and Krawiec, S., 1996. "Kinetic analyses of desulfurization of dibenzothiophene by rhodococcus erythropolis in continuous cultures". Applied and Environmental Microbiology, 62 (8): 3066-3068.

Yoshitaka, I., Konishi, J., Okada, H., Hirasawa, K., Onaka, T. and Suzuki, M., 2000. "Operon structure and functional analysis of the genes encoding thermophilic desulfurizing enzymes of paenibacillus sp. A11-2". Biochemical and Biophysical Research Communications, 270: 81-88. 